\title{
Galectin-9: An anticancer molecule for gallbladder carcinoma
}

\author{
TOMOKO TADOKORO $^{1}$, ASAHIRO MORISHITA ${ }^{1}$, SHINTARO FUJIHARA ${ }^{1}$, \\ HISAKAZU IWAMA ${ }^{2}$, TOSHIRO NIKI ${ }^{3}$, KOJI FUJITA ${ }^{1}$, EMIKO AKASHI ${ }^{1}$, \\ SHIMA MIMURA $^{1}$, KYOKO OURA ${ }^{1}$, TEPPEI SAKAMOTO ${ }^{1}$, TAKAKO NOMURA ${ }^{1}$, \\ JOJI TANI $^{1}$, HISAAKI MIYOSHI ${ }^{1}$, HIROHITO YONEYAMA ${ }^{1}$, TAKASHI HIMOTO ${ }^{1}$, \\ MITSUOMI HIRASHIMA ${ }^{3}$ and TSUTOMU MASAKI ${ }^{1}$ \\ ${ }^{1}$ Department of Gastroenterology and Neurology, ${ }^{2}$ Life Science Research Center, and \\ ${ }^{3}$ Department of Immunology and Immunopathology, Kagawa University, Kagawa, Japan
}

Received November 9, 2015; Accepted December 16, 2015

DOI: $10.3892 /$ ijo.2016.3347

\begin{abstract}
Gallbladder cancer (GBC) is the most common and aggressive type of biliary tract cancer. There are various histological types of GBC, and the vast majority of GBC cases are adenocarcinomas. Squamous and adenosquamous carcinomas are rare GBC subtypes that are traditionally considered to be more aggressive and to be associated with a poorer prognosis than adenocarcinoma. Galectin-9 (Gal-9), a tandem-repeattype galectin, has been reported to induce apoptosis-mediated elimination of various cancers, including hepatocellular carcinoma, cholangiocarcinoma, and hematologic malignancies. Therefore, we investigated the antitumor effects of Gal-9 on GBC in vitro and in vivo. In our in vitro experiments, Gal-9 suppressed cell proliferation in various GBC cell lines but not in the OCUG-1 cell line, which represents a poorly differentiated type of adenosquamous carcinoma. Gal-9 induced the apoptosis of Gal-9-sensitive GBC cells by increasing the levels of caspase-cleaved keratin 18 and phosphorylated p53. However, Gal-9 did not affect the expression of various cell cycle-related proteins. In addition, Gal-9 suppressed tumor growth by implanted human GBC cells in a xenograft model. Furthermore, Gal-9 induced the phosphorylation of the Ephrin type-B receptor, and the microRNA (miRNA) expression profile was markedly altered by Gal-9. Based on these results, various miRNAs might contribute to the suppression of tumor
\end{abstract}

Correspondence to: Dr Tsutomu Masaki, Department of Gastroenterology and Neurology, Kagawa University School of Medicine/ Graduate School of Medicine, 1750-1 Ikenobe, Miki-cho, Kita-gun, Kagawa 761-0793, Japan

E-mail: tmasaki@med.kagawa-u.ac.jp

Abbreviations: GBC, gallbladder carcinoma; Gal-9, galectin-9; CCK-8, Cell counting kit-8; p-RTK, phosphorylated receptor tyrosine kinase; cCK18, caspase-cleaved cytokeratin 18; EphB, Ephrin type-B receptor; miRNAs, microRNAs

Key words: galectin-9, gallbladder carcinoma, apoptosis, microRNA growth. Our data reveal that Gal-9 suppresses the growth of GBC, possibly by inducing apoptosis and altering miRNA expression. Thus, Gal-9 might serve as a therapeutic agent for the treatment of GBC.

\section{Introduction}

Gallbladder carcinoma (GBC), an aggressive type of biliary tract cancer, is the fifth most common gastrointestinal malignancy worldwide (1). In spite of recent advances in the understanding and treatment of other gastrointestinal malignancies, GBC has a very poor prognosis, with a $<10 \% 5$-year survival rate $(2,3)$. GBC often remains undiagnosed until the late disease stage because patients in the early stage of GBC often exhibit no symptoms. Given this background, it is important to develop a new therapeutic approach for GBC.

Galectin-9 (Gal-9) is a $\beta$-galactoside-binding lectin of the galectin family; this protein is involved in various biological processes, including cell aggregation, adhesion, chemoattraction, and apoptosis (4). The functions of Gal-9 have been reported to include the induction of apoptosis in T-cells, particularly CD $4^{+} \mathrm{Th} 1$ and Th17 cells, and the stimulation of regulatory T-cell activity (5-7). Interestingly, Gal-9 has been tested as a potential therapeutic agent for various autoimmune diseases (7) and allergic diseases (8). Furthermore, it has been reported that Gal-9 suppresses the cell proliferation and tumor growth of various human cancer types $(9,10)$, such as melanoma (11) and chronic myelogenous leukemia (12). We have previously shown that Gal-9 suppressed the cell proliferation and tumor growth of human hepatocellular carcinoma (HCC) and cholangiocarcinoma by inducing apoptosis, and we have identified several microRNAs (miRNAs) that are associated with the antitumor effect of Gal-9 $(13,14)$. However, the effect of Gal-9 on GBC remains unknown.

miRNAs, small, endogenous, non-coding RNAs that are 21-30 nucleotides in length, modulate the expression of various target genes at the post-transcriptional and translational levels $(15,16) ; 1,881$ human miRNAs have been registered at miRbase in release 21 (http://microrna.sanger.ac.uk/). However, little is known concerning the association of certain miRNAs with the antitumor effects of Gal-9 on GBC cells. 
Therefore, the purpose of the present study was to determine whether Gal-9 suppresses the tumor growth of GBC and to identify miRNAs associated with the antitumor effect of Gal-9.

\section{Materials and methods}

Chemicals. Recombinant mutant forms of human Gal-9 lacking linker peptides were expressed and purified as previously described (17). This mutant protein is stable against proteolysis (17).

Cell lines and culture. The human GBC cell lines NOZ and OCUG-1 were obtained from the Japanese Collection of Research Bioresources (Osaka, Japan). The GBC cell lines G-415 and TGBC24TKB were obtained from Riken Cell Bank (Tsukuba, Japan). NOZ cells were cultured in Williams' medium E (Sigma-Aldrich, St. Louis, MO, USA), and OCUG-1 cells were cultured in Dulbecco's modified Eagle's medium (Gibco, Tokyo, Japan) containing $0.5 \mathrm{mM}$ pyruvate. G-415 cells were cultured in RPMI-1640 medium, and TGBC24TKB cells were cultured in Dulbecco's modified Eagle's medium. All media contained $10 \%$ fetal bovine serum (Wako Pure Chemical Industries, Osaka, Japan) and $100 \mathrm{mg} / \mathrm{l}$ penicillin-streptomycin (Invitrogen, Tokyo, Japan), and the cells were incubated in a humidified atmosphere containing $5 \% \mathrm{CO}_{2}$ at $37^{\circ} \mathrm{C}$.

Cell proliferation assay. Cell proliferation assays were conducted using a cell counting kit-8 (CCK-8) (Dojindo Laboratories, Kumamoto, Japan) according to the manufacturer's instructions. Cells $\left(5.0 \times 10^{3}\right)$ from each cell line were seeded into the wells of a 96-well plate and were cultured in $100 \mu \mathrm{l}$ of the corresponding medium. After $24 \mathrm{~h}$, the seeded cells were treated with $0,0.1,0.3$, or $1 \mu \mathrm{M}$ Gal-9 diluted in the culture medium. At the indicated time-points, the medium was exchanged for $100 \mu \mathrm{l}$ of medium containing CCK-8 reagent, and the cells were incubated for $3 \mathrm{~h}$. The absorbance at a wavelength of $450 \mathrm{~nm}$ was measured in each well using an automated microplate reader.

Enzyme-linked immunosorbent assays (ELISAs) measuring apoptosis. Caspase-cleaved cytokeratin 18 (cCK18) was evaluated using the M30 Apoptosense ELISA kit obtained from PEVIVA AB (Bromma, Sweden) (18). The cells $\left(5 \times 10^{3}\right)$ were seeded in a 96-well plate and cultured for 6,24 or $48 \mathrm{~h}$ following the addition of $0.3 \mu \mathrm{M} \mathrm{Gal}-9$. The cells were lysed in polyoxyethylene octylphenyl ether (NP-40) (Wako Pure Chemical Industries). The subsequent ELISA procedures were performed according to the manufacturer's instructions. The abundance of antigen in the control and unknown samples was calculated via interpolation from a standard curve.

Analysis of apoptosis-related protein profiles using an antibody array. The cells were seeded in 100-mm culture dishes. Subsequently, the cells were treated with $0.3 \mu \mathrm{M}$ Gal-9 for $24 \mathrm{~h}$. The cells were lysed in Pro-Prep (iNtRON Biotechnology). A human apoptosis antibody array kit (R\&D Systems, Minneapolis, MN, USA) was used to measure apoptosis-related proteins according to the manufacturer's instructions. Briefly, in this method, proteins were captured by antibodies spotted on a nitrocellulose membrane. Then, the levels of apoptosis-related proteins were assessed using an HRP-conjugated antibody, followed by detection via chemiluminescence. Finally, each array membrane was exposed to X-ray film using a chemiluminescence detection system (Perkin-Elmer Co. Waltham, MA, USA).

Gel electrophoresis and western blot analysis. NOZ cells $\left(1.0 \times 10^{6} / \mathrm{dish}\right)$ were seeded in $100-\mathrm{mm}$ culture dishes and cultured for 24 or $48 \mathrm{~h}$, then $0.3 \mu \mathrm{M}$ Gal-9 was added. The cells were lysed using a protease inhibitor cocktail (Pro-Prep complete protease inhibitor mixture; iNtRON Biotechnology, Sungnam, Korea). Then, the samples were subjected to sodium dodecyl sulfate polyacrylamide gel electrophoresis (SDS-PAGE) on $12 \%$ agarose gels, and the proteins were transferred to nitrocellulose membranes. After blocking, the membranes were incubated in primary antibodies followed by secondary antibodies. The immunoreactive proteins were visualized on X-ray film using an enhanced chemiluminescence detection system (Perkin-Elmer Co.). The primary antibodies included an anti- $\beta$-actin monoclonal antibody (A5441, used at 1:10,000; Sigma-Aldrich) and antibodies against cyclin D1 (RB-9041, used at 1:1,000; Thermo Fisher Scientific, Waltham, MA,USA), cyclin E (used at 1:1,000; Thermo Fisher Scientific), Cdk6 (sc-177, used at 1:1,000, Santa Cruz Biotechnology, Santa Cruz, CA, USA), Cdk4 (sc-749, used at 1:1,000; Santa Cruz Biotechnology), and Cdk2 (sc-163, used at 1:2,000; Santa Cruz Biotechnology). The secondary antibodies included horseradish peroxidase (HRP)-linked anti-mouse and antirabbit IgG (used at 1:2,000; GE Healthcare, UK).

Flow cytometric analysis. To evaluate the mechanism by which Gal-9 inhibits tumor growth, the cell cycle profile was analyzed after treatment with Gal-9. Flow cytometric analysis was conducted using the Cell Cycle Phase Determination kit (Cayman Chemical Co., MI, USA) according to the manufacturer's instructions. NOZ or OCUG-1 cells $\left(1.0 \times 10^{6}\right.$ cells in a $100-\mathrm{mm}$ dish) were treated with 0 or $0.3 \mu \mathrm{MGal}-9$ for $48 \mathrm{~h}$. Then, the cells were analyzed using a Cytomics FC 500 flow cytometer (Beckman Coulter, Indianapolis, IN, USA). The results were analyzed using Kaluza software (Beckman Coulter).

Antibody arrays of phosphorylated receptor tyrosine kinases $(p-R T K s)$. Human p-RTK array kits (R\&D Systems) were used to measure protein phosphorylation according to the manufacturer's instructions. The cells were seeded in $100-\mathrm{mm}$ culture dishes and cultured for $24 \mathrm{~h}$, after $0.3 \mu \mathrm{M}$ Gal-9 was added. Briefly, in this method, proteins were captured by antibodies spotted on a nitrocellulose membrane. Then, the levels of the phosphoproteins were assessed using an HRP-conjugated antibody, followed by detection via chemiluminescence. Finally, each array membrane was exposed to X-ray film using a chemiluminescence detection system.

Xenograft model analysis. Animal experiments were performed according to the guidelines of the Committee on Experimental Animals of Kagawa University and the guidelines regarding the use of animal tissue by the UK National Cancer Research Institute (19). We purchased 20 female athymic mice (BALB/ c-nu/nu; 6-week-old; 18-23 g) from Japan SLC (Shizuoka, 

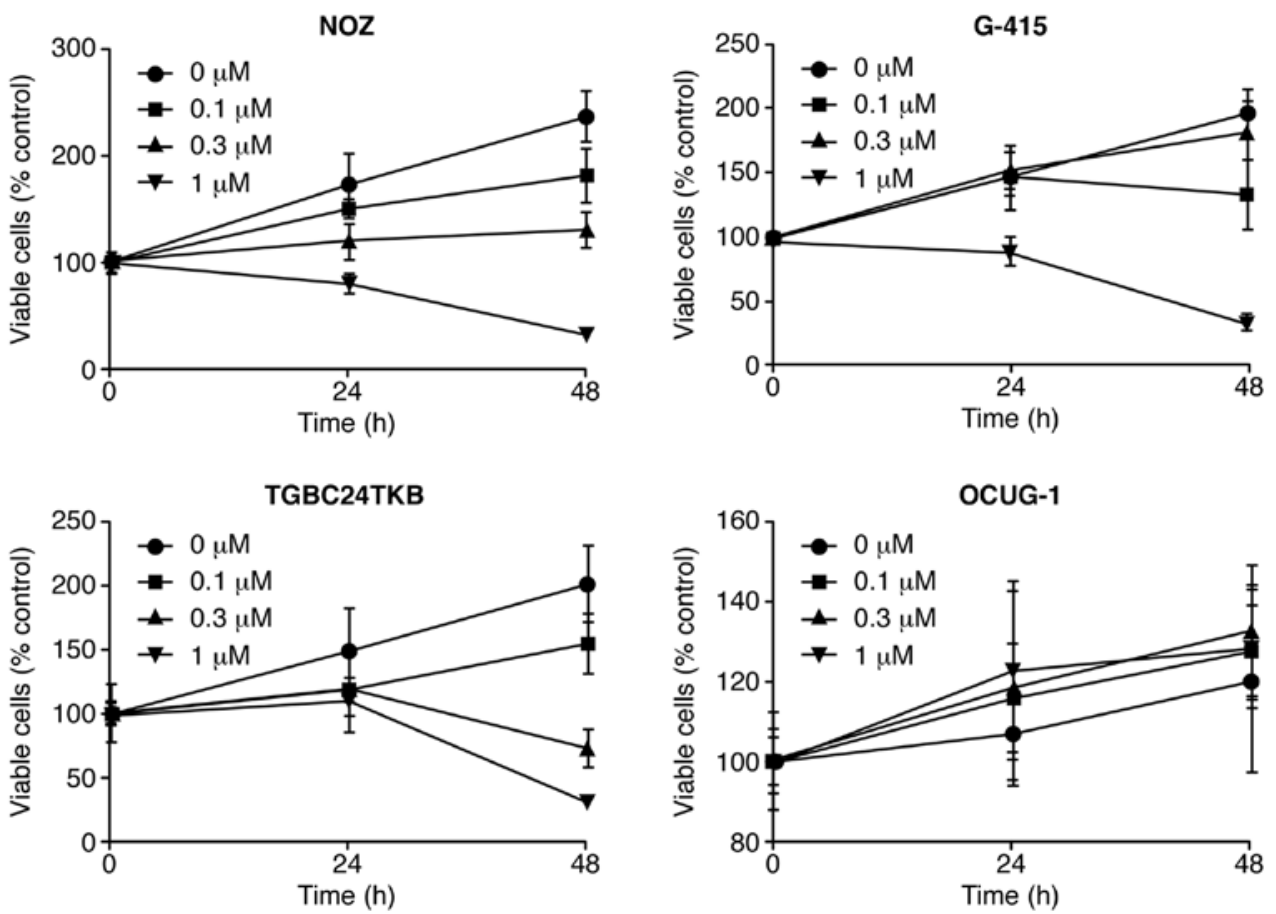

Figure 1. Galectin-9 (Gal-9) suppresses the proliferation of gallbladder carcinoma cell lines. NOZ, G-415, TGBC24TKB and OCUG-1 cells were seeded at 5,000 cells/well in 96-well plates. After $24 \mathrm{~h}$, Gal-9 $(0.1,0.3$, or $1 \mu \mathrm{M})$ was added to the culture medium. At $24 \mathrm{~h}$ after addition of the agent, the cell counting kit-8 assay was conducted as described in Materials and methods. The results are expressed as the percentages of viable cells relative to the control treatment $(0 \mu \mathrm{M})$, and the error bars represent SDs. For each cell line except for OCUG-1, cell viability at 24 and $48 \mathrm{~h}$ after Gal-9 treatment was significantly different compared with the control treatment $(0 \mu \mathrm{M})$.

Japan). The mice were housed in a temperature-controlled environment under a 12-h light/dark photoperiod. Each mouse was subcutaneously inoculated with NOZ cells $\left(3 \times 10^{6}\right.$ cells per animal) in the flank region of the mouse. Then, when their xenografts were palpable as a mass of $>3 \mathrm{~mm}$ in diameter, all recipient mice were randomly assigned to the control group or the treated group. The treated mice $(n=10)$ were intraperitoneally injected with $90 \mu \mathrm{g}$ of Gal-9 three times a week. PBS alone was administered to the control group at the same time-points. The tumor volume $\left(\mathrm{mm}^{3}\right)$ was calculated as [tumor length $(\mathrm{mm})$ $\mathrm{x}$ tumor width $\left.(\mathrm{mm})^{2}\right] / 2(20)$. The body weight of the mice was also recorded. All animals were sacrificed on day 24 after treatment, and all survived this treatment period.

Antibody arrays of phosphorylated receptor tyrosine kinases ( $p$-RTKs).Human p-RTK array kits (R\&D Systems, Minneapolis, MN, USA) were used to measure protein phosphorylation according to the manufacturer's instructions. The cells were seeded in 100-mm culture dishes and cultured for 24 hours, after $0.3 \mu \mathrm{M}$ Gal-9 was added. Briefly, in this method, proteins were captured by antibodies spotted on a nitrocellulose membrane. Then, the levels of the phosphoproteins were assessed using an HRP-conjugated antibody, followed by detection via chemiluminescence. Finally, each array membrane was exposed to X-ray film using a chemiluminescence detection system.

Analysis of miRNA arrays. The NOZ cells were treated with $0.3 \mu \mathrm{M}$ Gal-9 for $24 \mathrm{~h}$ and were stored in RNAprotect reagent (Qiagen, Venlo, The Netherlands). The samples for each cell line were processed for total RNA extraction using the miRNeasy Mini kit (Qiagen) according to the manufacturer's instructions. After measurement of RNA quantity and quality using an RNA 6000 Nano kit (Agilent Technologies, Santa Clara, CA, USA), the samples were labeled using a miRCURY Hy3 Power Labeling kit (Exiqon, Vedbaek, Denmark) and were hybridized to a human miRNA Oligo chip (v.20; Toray Industries, Tokyo, Japan). Scanning was conducted using the 3D-Gene Scanner 3000 (Toray Industries). 3D-Gene extraction version 1.2 software (Toray Industries) was used to calculate the raw intensity of the images. To determine the difference in miRNA expression between the Gal-9-treated and control samples, the raw data were analyzed using GeneSpring GX 10.0 software (Agilent Technologies). On the raw data that were above the background level, quantile normalization was performed. Differentially expressed miRNAs were determined by Mann-Whitney U test. Hierarchical clustering was performed using the farthest neighbor method with the absolute uncentered Pearson's correlation coefficient as a metric. A heat map was produced with the relative expression intensity for each miRNA, in which the base-2 logarithm of the intensity was median-centered for each row.

Statistical analysis. All analyses were conducted using GraphPad Prism software version 6.0 (GraphPad Software, San Diego, CA, USA). The unpaired t-test was conducted for comparison between the groups. A P-value of 0.05 was considered to indicate a significant difference between the groups.

\section{Results}

Gal-9 suppresses the proliferation of human GBC cells (NOZ, $G-415$, and TGBC24TKB cells) except for OCUG-1 cells. To 

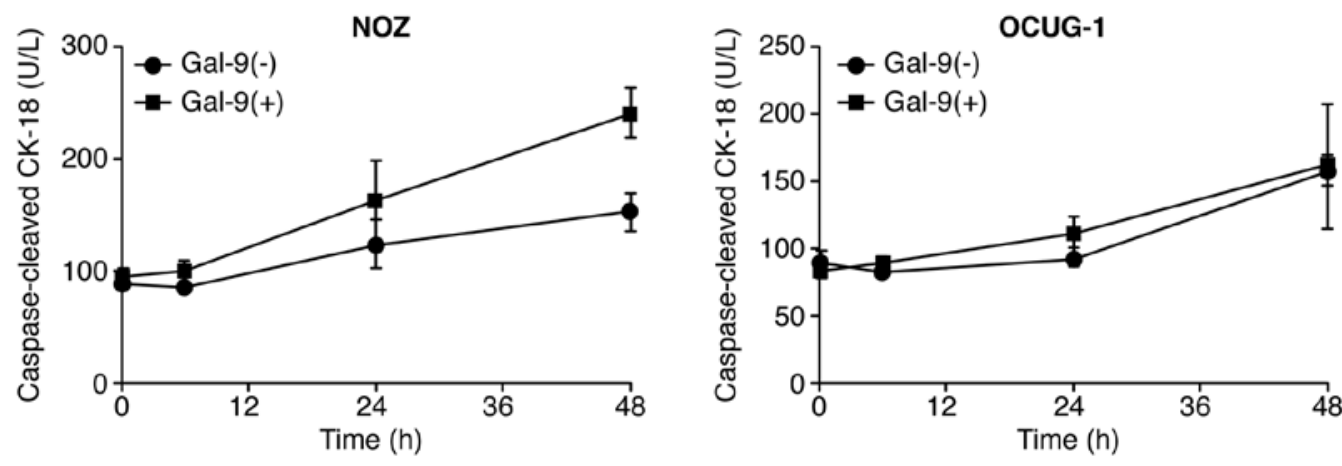

Figure 2. Gal-9 induces apoptosis of NOZ cells, but not OCUG-1 cells. The levels of caspase-cleaved keratin 18 (cCK18), which is specifically produced during apoptosis, was determined via ELISA. Cells were incubated in 0 or $0.3 \mu \mathrm{M} \mathrm{Gal-9}$. Gal-9 treatment increased the levels of cCK18 in NOZ cells but not in OCUG-1 cells. This result suggested that the apoptotic process following phosphatidylserine exposure proceeds to the degradation of intermediate filaments in cells. In NOZ cells, the cCK18 levels at 24 and $48 \mathrm{~h}$ were significantly different between the Gal-9 and control $(0 \mu \mathrm{M}$ Gal-9) treatments.

A

\begin{tabular}{|c|c|c|c|c|c|c|c|c|c|c|c|}
\hline $\begin{array}{c}\text { Reference } \\
\text { Spots }\end{array}$ & & & & & & & & & & & $\begin{array}{l}\text { Reference } \\
\text { Spots }\end{array}$ \\
\hline $\mathrm{Bad}$ & Bax & Bcl-2 & BCl-xL & $\begin{array}{c}\text { Pro- } \\
\text { Caspase-3 }\end{array}$ & $\begin{array}{l}\text { Cleaved } \\
\text { Caspase-3 }\end{array}$ & Catalase & CIAP-1 & CIAP-2 & Claspin & Clusterin & $\begin{array}{c}\text { Cytochro } \\
\text { me C }\end{array}$ \\
\hline $\begin{array}{l}\text { TRAIL } \\
\text { R1/DR4 }\end{array}$ & $\begin{array}{l}\text { TRAlL } \\
\text { R2/DR5 }\end{array}$ & FADD & $\begin{array}{c}\text { Fas/ } \\
\text { TNFRSF6 } \\
\text { /CD95 } \\
\end{array}$ & HIF-1a & $\begin{array}{c}\mathrm{HO}-1 / \\
\text { HMOX1/ } \\
\text { HSP32 }\end{array}$ & $\begin{array}{l}\mathrm{HO}-2 / \\
\text { HMOX2 }\end{array}$ & HSP 27 & HSP 60 & HSP 70 & $\begin{array}{c}\text { HTRA/ } \\
\text { Omi }\end{array}$ & Livin \\
\hline PON2 & $\begin{array}{l}\text { p21/CIP1/ } \\
\text { CDKN1A }\end{array}$ & P27/Kip1 & $\begin{array}{l}\text { Phospho- } \\
\text { p53(S15) }\end{array}$ & $\begin{array}{l}\text { Phospho- } \\
\text { p53(S46) }\end{array}$ & $\begin{array}{l}\text { Phospho- } \\
\text { p53(S392) }\end{array}$ & $\begin{array}{l}\text { Phospho- } \\
\text { Rad17 } \\
\text { (S635) } \\
\end{array}$ & $\begin{array}{l}\text { SMAC/ } \\
\text { DIABLO }\end{array}$ & Survivin & $\begin{array}{c}\text { TNF RI/ } \\
\text { TNF } \\
\text { RSF1A }\end{array}$ & XIAP & \begin{tabular}{|c|} 
PBS( Neg \\
ative \\
control) \\
\end{tabular} \\
\hline $\begin{array}{c}\text { Reference } \\
\text { Spots }\end{array}$ & & & & & & & & & & & $\begin{array}{c}\text { Reference } \\
\text { Spots }\end{array}$ \\
\hline
\end{tabular}

B

Gal-9(-)

NOZ

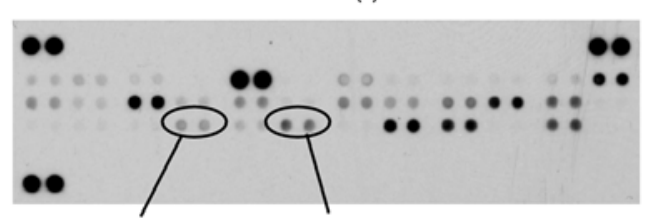

phospho-p53(S15) phospho-p53(S392)

Gal-9(-) OCUG-1

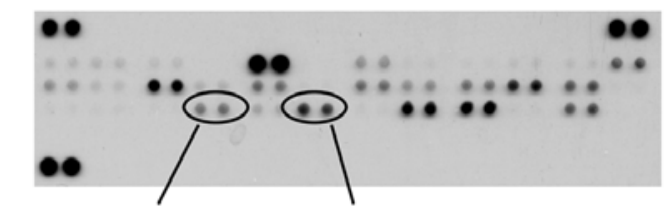

phospho-p53(S15) phospho-p53(S392)

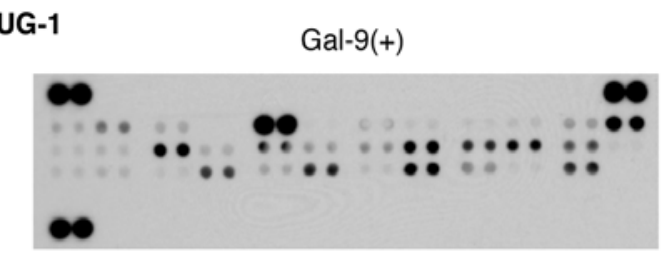

C

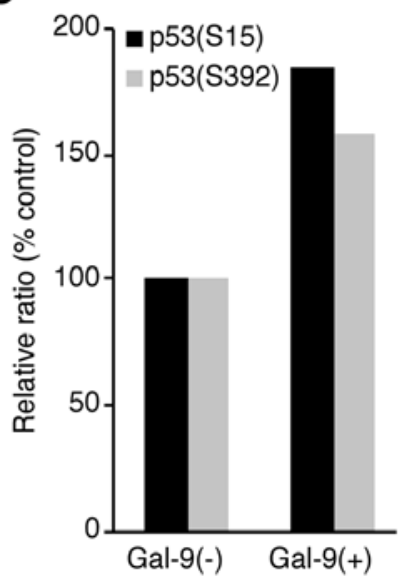

Figure 3. Effects of Gal-9 on the levels of apoptosis-related proteins in NOZ and OCUG-1 cells. (A) Template showing the location of apoptosis-related proteins on the human apoptosis antibody array. (B) Representative expression levels of various apoptosis-related proteins in NOZ and OCUG-1 cells treated with or without $0.3 \mu \mathrm{M} \mathrm{Gal}-9$ for $24 \mathrm{~h}$. Gal-9 increased the expression of phosphorylated p53 (phospho-p53), especially in NOZ cells. (C) Densitometric analysis showed that the phospho-p53 (S15) and phospho-p53 (S392) spots for the Gal-9-treated NOZ cells displayed 185.6 and $157.3 \%$ higher intensity than those for the untreated NOZ cells, respectively.

evaluate the effect of Gal-9 on the growth activity of human GBC cells in vitro, we examined the effect of Gal-9 on cell proliferation in four GBC cell lines (NOZ, G-415, TGBC24TKB, and OCUG-1) by culturing the cells for $48 \mathrm{~h}$ in the presence $(0.1,0.3$ or $1 \mu \mathrm{M})$ or absence of Gal-9 in the corresponding medium. We found that Gal-9 suppressed cell proliferation in three GBC cell lines (NOZ, G-415, and TGBC24TKB) in a dose-dependent manner (Fig. 1). In contrast, the OCUG-1 cell line, which represents a poorly differentiated adenocarcinoma exhibiting transition from adenocarcinoma to squamous cell carcinoma, were less susceptible to Gal-9 than the other GBC cell lines (Fig. 1). Therefore, the differences in sensitivity to 


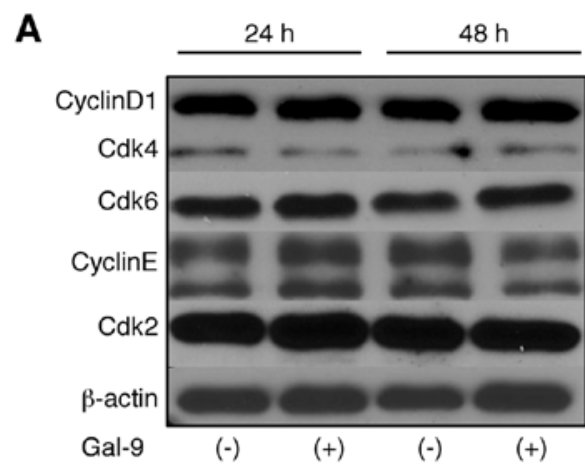

B

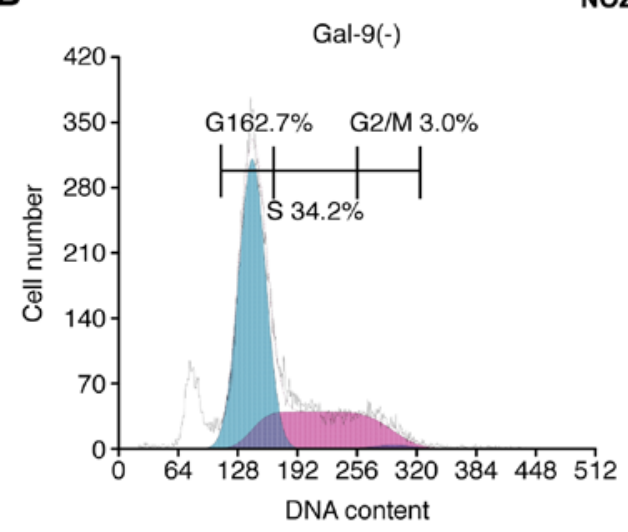

NOZ

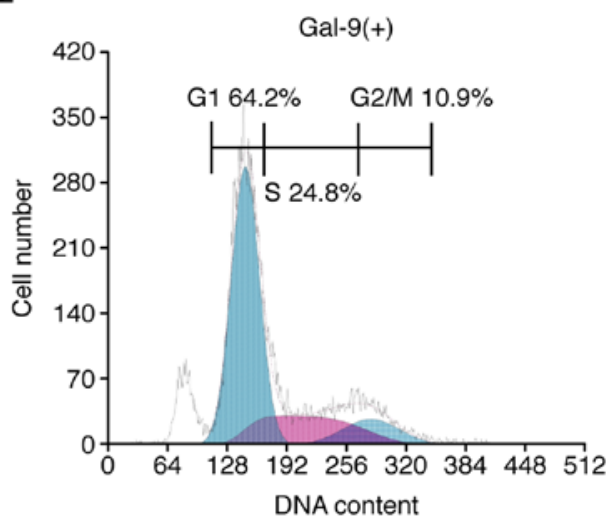

OCUG-1
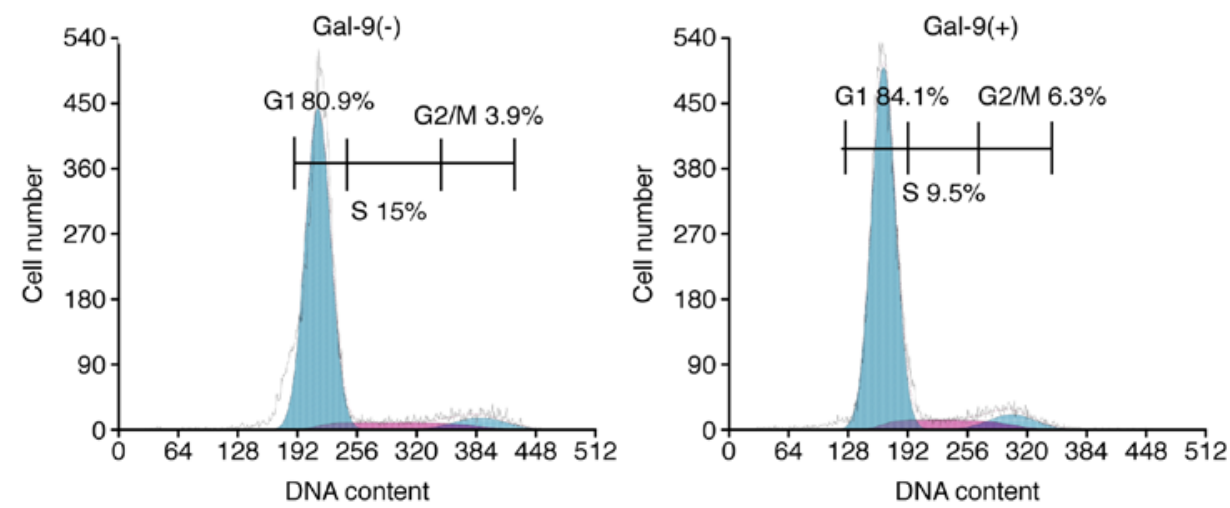

Figure 4. Western blotting and flow cytometric analysis of the cell cycle in NOZ and OCUG-1 cells. (A) The expression levels of cell cycle-related proteins (cyclin D1, Cdk4, Cdk6, cyclin E and Cdk2) in NOZ cells were not different between $0.3 \mu \mathrm{M}$ Gal-9 treatment and the control treatment based on western blotting. (B) Flow cytometric analysis of proliferating NOZ cells $48 \mathrm{~h}$ after the addition of $0.3 \mu \mathrm{M}$ Gal-9. The proportion of cells in G2/M phase was slightly increased in the NOZ cells treated with Gal-9 relative to the untreated NOZ cells.

Gal-9 between NOZ cells (Gal-9-sensitive cells) and OCUG-1 cells (Gal-9-resistant cells) were examined in human GBC.

Gal-9 induces apoptosis of Gal-9-sensitive GBC cells. To determine whether Gal-9 induced apoptosis, NOZ and OCUG-1 cells were treated with or without $0.3 \mu \mathrm{M} \mathrm{Gal}-9$, and the levels of cCK18 following treatment were determined using the M30 ELISA kit. We found that Gal-9 significantly increased the levels of cCK-18 in NOZ cells, but not in OCUG-1 cells (Fig. 2). These results highlight the difference in sensitivity to Gal-9 between NOZ cells and OCUG-1 cells. Consequently, Gal-9 suppressed the proliferation of Gal-9-sensitive GBC cells, which represent a well-to-moderately differentiated cancer type, by inducing apoptosis. In contrast, Gal-9-resistant cells, which represent a poorly differentiated cancer type, were less sensitive to the anti-proliferative effect of Gal-9.

Effects of Gal-9 on the levels of apoptosis-associated proteins in Gal-9-sensitive versus Gal-9-resistant GBC cells. We used an apoptosis array system to identify which apoptosis-associated proteins are involved in the antitumor effects of Gal-9. Using an antibody array enabled the screening of the expression of 35 apoptosis-associated proteins in NOZ and OCUG-1 cells in the presence or absence of Gal-9. Gal-9 increased the expression of phosphorylated p53 (phospho-p53), especially in NOZ cells. Densitometry showed that the intensity of the phospho-p53 spot (S15) for the Gal-9-treated NOZ cells was $185.5 \%$ of that for untreated NOZ cells (Fig. 3). However, the 


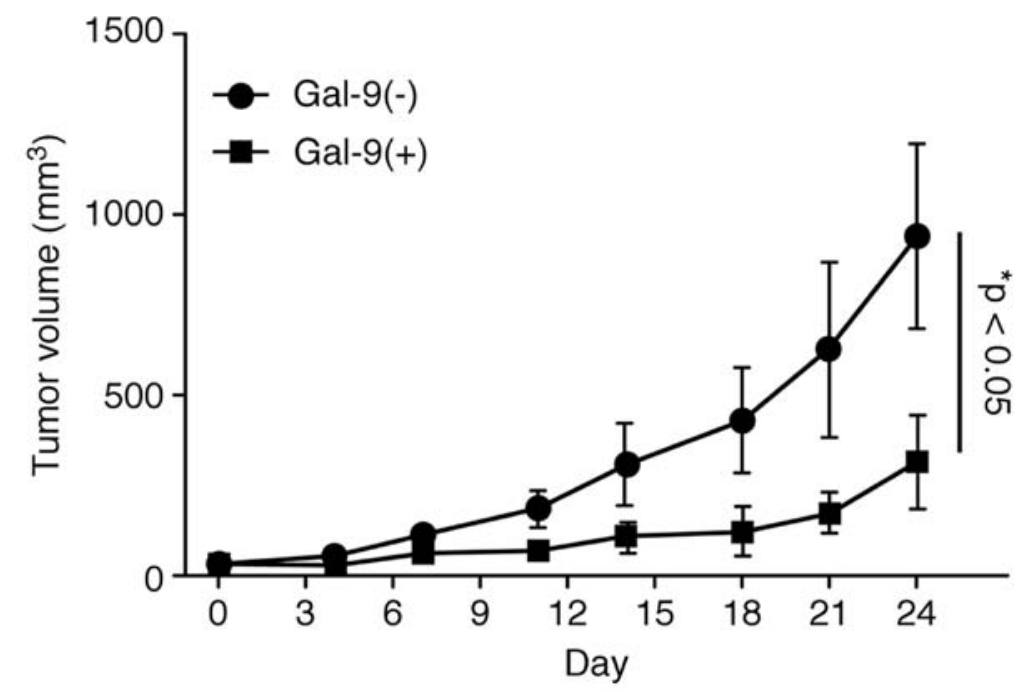

Gal-9(-)

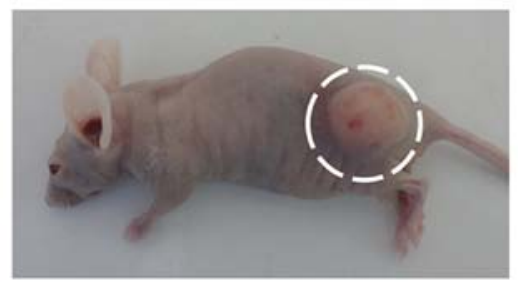

Gal-9(+)

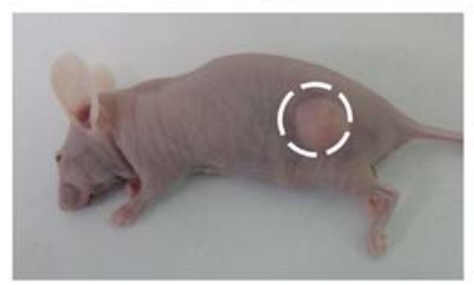

Figure 5. Antitumor effect of Gal-9 on established gallbladder carcinoma in vivo. NOZ cells were subcutaneously implanted into the flanks of nude mice. When the tumors became palpable, $90 \mu \mathrm{g}$ of Gal-9 was intraperitoneally injected 3 times a week. The tumor volume was calculated as follows: tumor volume (mm $\left.{ }^{3}\right)$ $=\left[\right.$ tumor length $(\mathrm{mm}) \times$ tumor width $\left.(\mathrm{mm})^{2}\right] / 2$. All animals were sacrificed on day 24 after treatment, and all animals survived this treatment period. The tumors were significantly smaller in Gal-9-treated mice than in control mice. Each point represents the mean \pm SD of 10 animals based on two-way ANOVA.

A

\begin{tabular}{|c|c|c|c|c|c|c|c|c|c|c|c|}
\hline $\begin{array}{c}\text { Reference } \\
\text { Spots }\end{array}$ & & & & & & & & & & & $\begin{array}{c}\text { Reference } \\
\text { Spots }\end{array}$ \\
\hline EGF R & ErbB2 & ErbB3 & ErbB4 & FGF R1 & FGF R2a & FGF R3 & FGF R4 & Insulin R & IGF-1 R & Axl & Dtk \\
\hline Mer & HGF R & MSP R & PDFG Ra & PDFG Rb & SCF R & Flt-3 & M-CSF R & C-Ret & ROR1 & ROR2 & Tie-1 \\
\hline Tie-2 & TrkA & TrkB & TrkC & VEGF R1 & VEGF R2 & VEGF R3 & MuSK & EphA1 & EphA2 & EphA3 & EphA4 \\
\hline EphA6 & EphA7 & EphB1 & EphB2 & EphB4 & EphB6 & ALK & DDR1 & DDR2 & EphA5 & EphA10 & \\
\hline $\begin{array}{c}\text { Reference } \\
\text { Spots }\end{array}$ & & EphB3 & PYK & & & & & & & & PBS \\
\hline
\end{tabular}

B

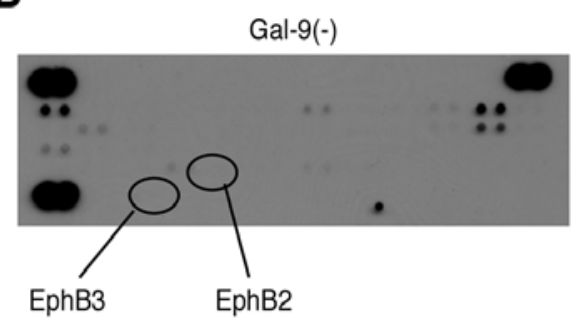

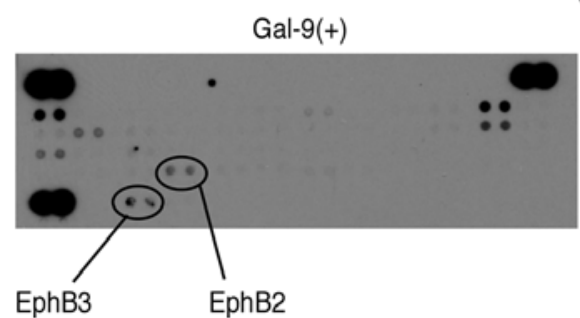

C

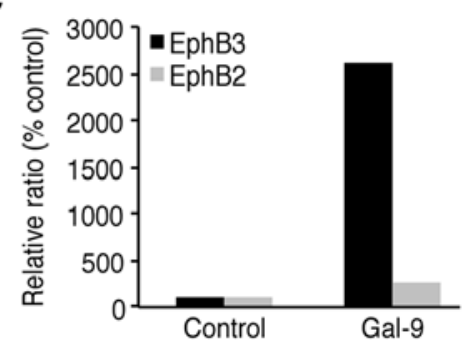

Figure 6. Effects of Gal-9 on the levels of phosphorylated receptor tyrosine kinases (p-RTKs) in NOZ cells. (A) Template showing the location of tyrosine kinase antibodies spotted on the human p-RTK array. (B) Representative expression of various p-RTKs in NOZ cells treated with or without Gal-9. (C) Based on densitometric analysis, the intensity of the Ephrin type-B receptor (EphB)3 and EphB2 spots for the Gal-9-treated cells were 26.15 and 2.6 times higher relative to those for the untreated cells, respectively. 


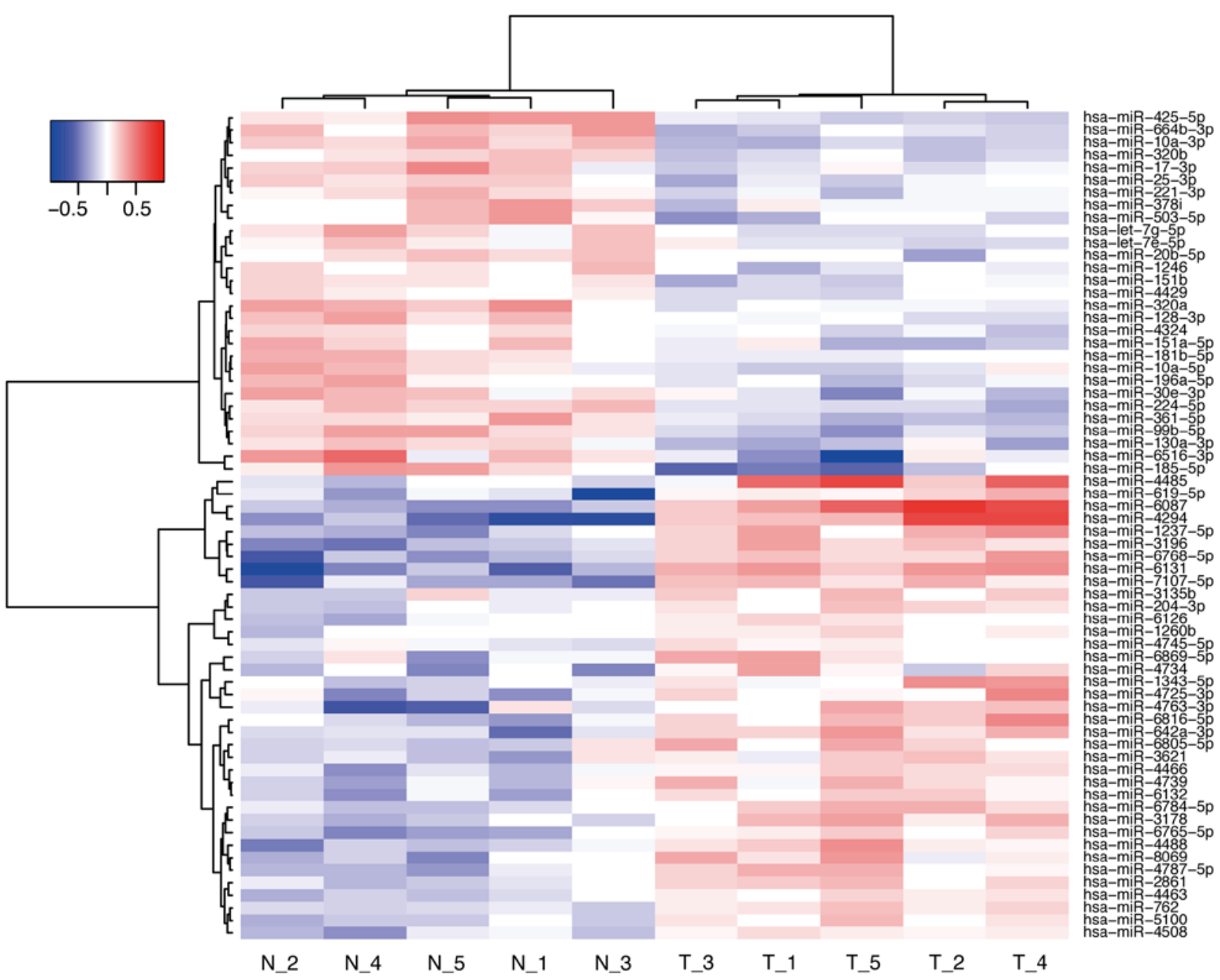

Figure 7. Hierarchical clustering analysis of NOZ cells with or without Gal-9 treatment. NOZ cells were clustered according to the expression profiles of 66 differentially expressed miRNAs between tumor cells exposed to Gal-9 and those not treated to Gal-9. The analyzed samples are shown in the columns, and the miRNAs are presented in separate rows. N_1-5, the group not treated with Gal-9, and T_1-5, those treated with Gal-9. The color scale shown on the top indicates the relative expression levels of the miRNAs; red, a high expression level, and blue, a low expression level.

expression levels of apoptosis-associated proteins other than phospho-p53 were not affected by Gal-9.

Effects of Gal-9 on the cell cycle in Gal-9-sensitive versus Gal-9-resistant GBC cells. The possible effect of Gal-9 on cell cycle progression in GBC cells was examined via flow cytometry. Our data suggested that the proportion of Gal-9treated NOZ cells in the $\mathrm{S}$ phase and the $\mathrm{G} 2 / \mathrm{M}$ phase was slightly decreased and increased, respectively (Fig. 4A). Conversely, OCUG-1 cells did not display any difference in cell cycle progression in response to Gal-9 treatment (Fig. 4A).

The effects of Gal-9 on the protein expression of various cell cycle-related molecules in NOZ cells were evaluated by western blotting. The cells were treated with 0 or $0.3 \mu \mathrm{M} \mathrm{Gal}-9$ for 24-48 h. Then, we examined the levels of various cell cyclerelated molecules, such as cyclin D1, Cdk4, Cdk6, cyclin E, and $\mathrm{Cdk} 2$. However, no significant differences in the expression of these cell cycle-related proteins were detected (Fig. 4B).

These results suggested that Gal-9 suppresses the proliferation of Gal-9-sensitive NOZ cells, predominantly by inducing apoptosis, but not by promoting cell cycle arrest.
Gal-9 suppresses tumor cell growth in vivo. Then experiments were performed to clarify whether Gal-9 exhibits tumor-suppressive activity in vivo. Nude mice were subcutaneously injected with NOZ cells, followed by intraperitoneal injection of Gal-9. The Gal-9-treated mice exhibited significantly suppressed NOZ cell-based tumor growth compared to the untreated mice (Fig. 5). However, Gal-9 had no further apparent effects on these mice, as Gal-9 treatment did not affect their body weight and all animals survived the entire experimental period.

Effects of Gal-9 on the levels of p-RTKs in NOZ cells. We used a p-RTK array system to identify the key RTKs associated with the antitumor effect of Gal-9. Using an antibody array enabled the screening of the expression of 49 activated RTKs in NOZ cells. Gal-9 increased the expression of phosphorylated Ephrin type-B receptor $(E p h B) 3$ and EphB2. Densitometric analysis revealed that the EphB3 and EphB2 spots for the Gal-9-treated cells were 26.15 times and 2.6 times more intense than those for the untreated cells, respectively (Fig. 6).

Effects of Gal-9 on miRNA expression in NOZ cells. To further examine the antitumor effect of Gal-9, we screened the expres- 
Table I. Statistical results of miRNAs in NOZ cells treated with Gal-9 compared with untreated NOZ cells.

\begin{tabular}{|c|c|c|c|}
\hline $\begin{array}{l}\text { Upregulated } \\
\text { microRNAs }\end{array}$ & $\begin{array}{l}\text { Fold-change } \\
\text { (Gal-9 treated/ } \\
\text { non-treated) }\end{array}$ & P-value & $\begin{array}{c}\text { Chromosomal } \\
\text { localization }\end{array}$ \\
\hline
\end{tabular}

\begin{tabular}{|c|c|c|c|}
\hline hsa-miR-4294 & 1.97 & 0.0079 & 10 \\
\hline hsa-miR-6087 & 1.80 & 0.0117 & $\mathrm{X}$ \\
\hline hsa-miR-6131 & 1.74 & 0.0079 & 5 \\
\hline hsa-miR-7107-5p & 1.47 & 0.0079 & 12 \\
\hline hsa-miR-6768-5p & 1.45 & 0.0079 & 16 \\
\hline hsa-miR-4485 & 1.44 & 0.0317 & 11 \\
\hline hsa-miR-3196 & 1.41 & 0.0079 & 20 \\
\hline hsa-miR-1237-5p & 1.38 & 0.0079 & 11 \\
\hline hsa-miR-642a-3p & 1.34 & 0.0079 & $19 q 13.32$ \\
\hline hsa-miR-4763-3p & 1.32 & 0.0317 & 22 \\
\hline hsa-miR-619-5p & 1.31 & 0.0079 & $12 \mathrm{q} 24.11$ \\
\hline hsa-miR-4488 & 1.30 & 0.0119 & 11 \\
\hline hsa-miR-6816-5p & 1.30 & 0.0159 & 22 \\
\hline hsa-miR-3178 & 1.30 & 0.0119 & 16 \\
\hline hsa-miR-6765-5p & 1.28 & 0.0079 & 14 \\
\hline hsa-miR-8069 & 1.27 & 0.0361 & 21 \\
\hline hsa-miR-4787-5p & 1.27 & 0.0153 & 3 \\
\hline hsa-miR-4725-3p & 1.26 & 0.0317 & 17 \\
\hline hsa-miR-6784-5p & 1.25 & 0.0079 & 17 \\
\hline hsa-miR-4734 & 1.24 & 0.0317 & 17 \\
\hline hsa-miR-4739 & 1.23 & 0.0273 & 17 \\
\hline hsa-miR-6132 & 1.22 & 0.0159 & 7 \\
\hline hsa-miR-4466 & 1.22 & 0.0119 & 6 \\
\hline hsa-miR-6805-5p & 1.22 & 0.0317 & 19 \\
\hline hsa-miR-1343-5p & 1.21 & 0.0465 & 11 \\
\hline hsa-miR-2861 & 1.21 & 0.0157 & 9 \\
\hline hsa-miR-4508 & 1.21 & 0.0119 & 15 \\
\hline hsa-miR-6869-5p & 1.21 & 0.0459 & 20 \\
\hline hsa-miR-5100 & 1.20 & 0.0255 & \\
\hline hsa-miR-762 & 1.20 & 0.0117 & 16 \\
\hline hsa-miR-3621 & 1.20 & 0.0317 & 9 \\
\hline hsa-miR-4463 & 1.19 & 0.0119 & 6 \\
\hline hsa-miR-204-3p & 1.16 & 0.0196 & $9 q 21.12$ \\
\hline hsa-miR-3135b & 1.15 & 0.0356 & 3 \\
\hline hsa-miR-6126 & 1.14 & 0.0465 & 16 \\
\hline hsa-miR-1260b & 1.09 & 0.0238 & 14 \\
\hline hsa-miR-4745-5p & 1.09 & 0.0317 & 19 \\
\hline
\end{tabular}

Downregulated Fold-change P-value Chromosomal microRNAs (Gal-9 treated/

localization non-treated)

\begin{tabular}{lllc}
\hline hsa-miR-185-5p & 0.69 & 0.0212 & $22 \mathrm{q} 11.21$ \\
hsa-miR-6516-3p & 0.70 & 0.0159 & 17 \\
hsa-miR-99b-5p & 0.74 & 0.0119 & $19 \mathrm{q} 13.41$ \\
hsa-miR-425-5p & 0.74 & 0.0117 & $3 \mathrm{p} 21.31$ \\
hsa-miR-10a-3p & 0.75 & 0.0119 & $17 \mathrm{q} 21.32$
\end{tabular}

Table I. Continued.

\begin{tabular}{|c|c|c|c|}
\hline $\begin{array}{l}\text { Downregulated } \\
\text { microRNAs }\end{array}$ & $\begin{array}{l}\text { Fold-change } \\
\text { (Gal-9 treated/ } \\
\text { non-treated) }\end{array}$ & P-value & $\begin{array}{l}\text { Chromosomal } \\
\text { localization }\end{array}$ \\
\hline hsa-miR-664b-3p & 0.77 & 0.0119 & 1 \\
\hline hsa-miR-361-5p & 0.77 & 0.0119 & $\mathrm{Xq} 21.2$ \\
\hline hsa-miR-224-5p & 0.78 & 0.0119 & $\mathrm{Xq} 28$ \\
\hline hsa-miR-30e-3p & 0.79 & 0.0317 & $1 \mathrm{p} 34.2$ \\
\hline hsa-miR-130a-3p & 0.79 & 0.0159 & $11 q 12.1$ \\
\hline hsa-miR-320a & 0.80 & 0.0119 & $8 p 21.3$ \\
\hline hsa-miR-503-5p & 0.80 & 0.0278 & $\mathrm{Xq} 26.3$ \\
\hline hsa-miR-151a-5p & 0.81 & 0.0356 & $8 \mathrm{q} 24.3$ \\
\hline hsa-miR-17-3p & 0.82 & 0.0317 & $13 q 31.3$ \\
\hline hsa-miR-25-3p & 0.83 & 0.0147 & $7 q 22.1$ \\
\hline hsa-miR-320b & 0.83 & 0.0117 & \\
\hline hsa-miR-10a-5p & 0.83 & 0.0269 & $17 q 21.32$ \\
\hline hsa-miR-196a-5p & 0.84 & 0.0079 & $17 \mathrm{q} 21.32$ \\
\hline hsa-miR-128-3p & 0.84 & 0.0159 & \\
\hline hsa-miR-221-3p & 0.84 & 0.0107 & Xp11.3 \\
\hline hsa-let-7g-5p & 0.84 & 0.0345 & $3 \mathrm{p} 21.1$ \\
\hline hsa-miR-151b & 0.85 & 0.0147 & 14 \\
\hline hsa-miR-378i & 0.85 & 0.0361 & 22 \\
\hline hsa-miR-181b-5p & 0.86 & 0.0119 & \\
\hline hsa-miR-20b-5p & 0.86 & 0.0248 & $\mathrm{Xq} 26.2$ \\
\hline hsa-miR-1246 & 0.87 & 0.0200 & 2q31.1 \\
\hline hsa-let-7e-5p & 0.87 & 0.0452 & $19 q 13.41$ \\
\hline hsa-miR-4324 & 0.87 & 0.0079 & 19 \\
\hline hsa-miR-4429 & 0.88 & 0.0114 & 2 \\
\hline
\end{tabular}

sion levels of miRNAs in NOZ cells and compared the miRNA profiles obtained with or without Gal-9 treatment. NOZ cells were treated with 0 or $0.3 \mu \mathrm{M}$ Gal-9 for $24 \mathrm{~h}$. Unsupervised hierarchical clustering analysis showed that the treated group clustered separately from the control group (Fig. 7). We identified 66 miRNAs that were differentially expressed between the two groups of NOZ cells (37 upregulated miRNA and 29 downregulated miRNAs) (Table I).

\section{Discussion}

GBC is the most common malignant tumor found in the biliary tract and the fifth most common digestive malignancy $(1,21)$. Previously, we demonstrated that Gal-9 suppressed cell proliferation and tumor growth in hepatobiliary malignancies $(13,14)$. The present study revealed that Gal-9 led to dose-dependent inhibition of cell proliferation in three GBC cell lines (NOZ, TGBC24TKB and G-415) but not in the OCUG-1 cell line. The OCUG-1 cell line represents a poorly differentiated adenocarcinoma and is regarded as a unique cell line because the corresponding cancer is a transitional form from adenocarcinoma to squamous cell carcinoma (22). Generally, GBC is classified into three histological types: 
adenocarcinoma, which accounts for $90 \%$ of all primary gallbladder cancer cases, followed by squamous carcinoma and adenosquamous carcinoma, both of which display an incidence of $1.4-10.4 \%(23,24)$. Although the clinical features of squamous carcinoma and adenosquamous carcinoma are similar to adenocarcinoma of the gallbladder, squamous and adenosquamous carcinoma patients frequently presented with an advanced stage of cancer. Additionally, these two forms of GBC are traditionally considered as more aggressive and to be associated with a poorer prognosis than adenocarcinoma $(25,26)$. Accordingly, the data from the present study indicated that the squamous and adenosquamous forms of GBC were more resistant to Gal-9 treatment due to their poorly differentiated phenotype compared to well-to-moderately differentiated GBC types.

Gal-9, a tandem-repeat-type galectin family member that consists of two carbohydrate recognition domains connected by a linker peptide (27), was first described as an eosinophil chemoattractant $(4,28)$. Further research showed that Gal-9 induces apoptosis in T-cells and stimulates regulatory T-cell activity (5-7). Previous findings suggested that Gal-9 suppresses the proliferation of melanoma (11) and chromic myeloid leukemia (12). Regarding the mechanism underlying Gal-9-induced cell growth inhibition in various cancers, Gal-9 induces cancer cell death via an apoptotic signaling pathway (11-13). This apoptotic signaling in multiple myeloma was caspase-dependent and was induced by the activation of the MAP kinases JNK and p38 $(22,29)$. Alternatively, Gal-9 induced apoptosis in chronic myelogenous leukemia by inducing Noxa (12). In the present study, Gal-9 increased the levels of cCK18 in NOZ cells, which are sensitive to Gal-9. A neo-epitope in cytokeratin 18 becomes available upon an early caspase cleavage event during apoptosis, and the monoclonal antibody M30, which is specific for this site, can be utilized to specifically detect apoptotic cells (30). Additionally, Gal-9 increased the phosphorylation of $\mathrm{p} 53$, especially in NOZ cells. The p53 protein is activated by phosphorylation to induce tumor cell apoptosis (31). Thus, we regarded phospho-p53 as a key apoptosis-related protein responsible for the antitumor effect of Gal-9.

In contrast, Gal-9 treatment for 24 or $48 \mathrm{~h}$ did not affect the G0-G1 transition or the expression levels of cell cycle-related proteins. These data suggest that Gal-9 suppresses cell proliferation in Gal-9-sensitive GBC cell lines by inducing apoptosis but not by promoting cell cycle arrest. In contrast, Gal-9 did not induce apoptosis of OCUG-1 cells, which are more resistant to Gal-9.

Moreover, Gal-9 treatment leads to changes in the phosphorylation status of various proteins. We detected increases in EphB3 and EphB2 phosphorylation in GBC cells in response to Gal-9 treatment based on p-RTK array analysis. EphB receptors are implicated in regulating the malignant progression of cancer. EphB2 and EphB3 show similar changes in expression during colorectal cancer progression, and EphB receptor activity suppresses cancer progression by controlling cellular positioning and restricting tumor cell motility (32,33). A more recent study suggested that the expression of EphB1 and Ephrin-B is an independent prognostic factor of not only adenocarcinoma but also squamous adenocarcinoma and adenosquamous carcinoma of the gallbladder (34). These results raise the possibility that EphB signaling pathway may be relevant for antitumor effect of galectin-9 in GBC cells.

The miRNAs associated with the antitumor effects of Gal-9 were analyzed using miRNA expression arrays. It has become apparent that miRNA expression is associated with various cancers (16). Our previous studies reported that miRNAs lead to apoptosis as a consequence of the antitumor effect of Gal-9 in HCC and cholangiocarcinoma $(11,12)$. Hierarchical cluster analyses were performed to clarify the alteration in the expression of miRNAs by Gal-9 treatment. We identified 66 differentially expressed miRNAs (37 upregulated and 29 downregulated) in NOZ cells with or without Gal-9 treatment. Several miRNAs that were downregulated by Gal-9 treatment have been reported to be associated with cancer cell apoptosis. For instance, miR-10a has been reported to be upregulated in several solid tumors including pancreatic cancer (35) and lung cancer (36). miR-10a targets the phosphatase and tensin homolog (PTEN), and miR-10a promotes the migration, invasion, and growth of non-small cell lung cancer by regulating the PTEN/AKT/ERK signaling pathway (36). In addition, miR-224 promotes lung cancer cells proliferation and migration by direct targeting of caspase- 3 and caspase-7 (37), and downregulation of miR-224 might be associated with inhibition of cancer progression by inducing apoptosis. Furthermore, these findings suggest that Gal-9 suppresses cell proliferation by altering the expression of several miRNAs.

Gemcitabine-based chemotherapies are still the main therapeutic regimens for patients with unresectable advanced or metastatic GBC (38). Gemcitabine acts by targeting ribonucleotide reductase M1 (RRM1) to elongate DNA (39) and by targeting cyclin D1 to induce cell cycle arrest (40). However, the use of gemcitabine alone is inadequate, and combination therapy of gemcitabine with other antitumor drug has been attempted. These results suggest that a combination of Gal-9 with other antitumor drugs that induce cell cycle arrest would be even more effective for patients with GBC.

In conclusion, Gal-9 suppresses the cell proliferation and tumor growth of human GBC in vitro and in vivo. The antitumor effect of Gal-9 appears to depend on several pathways, such as the induction of apoptosis in cancer cells via the phosphorylation of $\mathrm{p} 53$, the activation of the EphB receptor and the alteration of expression miRNAs; however, Gal-9 did not affect the cell cycle. Thus, Gal-9 may represent a novel therapeutic agent as an adjunct to conventional chemotherapy for the treatment of GBC.

\section{Acknowledgements}

Toshiro Niki and Mitsuomi Hirashima are board members of GalPharma Co., Ltd. These two authors have the following patent related to material pertinent to this study: 'Novel modified galectin 9 proteins and use thereof', which was applied for by GalPharma and was issued in Japan (4792390), the USA $(8,268,324)$, the EPC $(1736541)$, Canada $(2,561,696)$, India (239130), and Korea [(10-1222281) as of 2013.12.2]. These two authors have the following products related to material pertinent to this study: stable-form Gal-9. We thank Ms. Kayo Endo, Ms. Fuyuko Kokado, Ms. Keiko Fujikawa, Ms. Kayo Hirose, Ms. Miwako Watanabe, Ms. Noriko Murao, and Ms. Kayo Ogawa for providing technical assistance. 


\section{References}

1. Bal MM, Ramadwar M, Deodhar K and Shrikhande S: Pathology of gallbladder carcinoma: Current understanding and new perspectives. Pathol Oncol Res 21: 509-525, 2015.

2. Randi G, Franceschi S and La Vecchia C: Gallbladder cancer worldwide: Geographical distribution and risk factors. Int J Cancer 118: 1591-1602, 2006.

3. Dwivedi AN, Jain S and Dixit R: Gall bladder carcinoma: Aggressive malignancy with protean loco-regional and distant spread. World J Clin Cases 3: 231-244, 2015.

4. Hirashima M, Kashio Y, Nishi N, Yamauchi A, Imaizumi TA, Kageshita T, Saita N and Nakamura T: Galectin-9 in physiological and pathological conditions. Glycoconj J 19: 593-600, 2004.

5. Zhu C, Anderson AC, Schubart A, Xiong H, Imitola J, Khoury SJ, Zheng XX, Strom TB and Kuchroo VK: The Tim-3 ligand galectin-9 negatively regulates $\mathrm{T}$ helper type 1 immunity. Nat Immunol 6: 1245-1252, 2005.

6. Oomizu S, Arikawa T, Niki T, Kadowaki T, Ueno M, Nishi N, Yamauchi A and Hirashima M: Galectin-9 suppresses Th17 cell development in an IL-2-dependent but Tim-3-independent manner. Clin Immunol 143: 51-58, 2012.

7. Seki M, Oomizu S, Sakata KM, Sakata A, Arikawa T, Watanabe K, Ito K, Takeshita K, Niki T, Saita N, et al: Galectin-9 suppresses the generation of Th17, promotes the induction of regulatory $\mathrm{T}$ cells, and regulates experimental autoimmune arthritis. Clin Immunol 127: 78-88, 2008.

8. Niki T, Tsutsui S, Hirose S, Aradono S, Sugimoto Y, Takeshita K, Nishi N and Hirashima M: Galectin-9 is a high affinity IgE-binding lectin with anti-allergic effect by blocking IgE-antigen complex formation. J Biol Chem 284: 32344-32352, 2009.

9. Wiersma VR, de Bruyn M, Helfrich W and Bremer E: Therapeutic potential of Galectin-9 in human disease. Med Res Rev 33 (Suppl 1): E102-E126, 2013.

10. Fujihara S, Mori H, Kobara H, Rafiq K, Niki T, Hirashima M and Masaki T: Galectin-9 in cancer therapy. Recent Pat Endocr Metab Immune Drug Discov 7: 130-137, 2013.

11. Kageshita T, Kashio Y, Yamauchi A, Seki M, Abedin MJ, Nishi N, Shoji H, Nakamura T, Ono T and Hirashima M: Possible role of galectin-9 in cell aggregation and apoptosis of human melanoma cell lines and its clinical significance. Int J Cancer 99: 809-816, 2002

12. Kuroda J, Yamamoto M, Nagoshi H, Kobayashi T, Sasaki N, Shimura Y, Horiike S, Kimura S, Yamauchi A, Hirashima M, et al: Targeting activating transcription factor 3 by Galectin-9 induces apoptosis and overcomes various types of treatment resistance in chronic myelogenous leukemia. Mol Cancer Res 8: 994-1001, 2010

13. Fujita K, Iwama H, Sakamoto T, Okura R, Kobayashi K, Takano J, Katsura A, Tatsuta M, Maeda E, Mimura S, et al: Galectin-9 suppresses the growth of hepatocellular carcinoma via apoptosis in vitro and in vivo. Int J Oncol 46: 2419-2430, 2015.

14. Kobayashi K, Morishita A, Iwama H, Fujita K, Okura R, Fujihara S, Yamashita T, Fujimori T, Kato K, Kamada H, et al: Galectin-9 suppresses cholangiocarcinoma cell proliferation by inducing apoptosis but not cell cycle arrest. Oncol Rep 34: $1761-1770,2015$.

15. Zamore PD and Haley B: Ribo-gnome: The big world of small RNAs. Science 309: 1519-1524, 2005.

16. Morishita A and Masaki T: miRNA in hepatocellular carcinoma. Hepatol Res 45: 128-141, 2015.

17. Nishi N, Itoh A, Fujiyama A, Yoshida N, Araya S, Hirashima M, Shoji $\mathrm{H}$ and Nakamura T: Development of highly stable galectins: Truncation of the linker peptide confers protease-resistance on tandem-repeat type galectins. FEBS Lett 579: 2058-2064, 2005 .

18. Schutte B, Henfling M, Kölgen W, Bouman M, Meex S, Leers MP, Nap M, Björklund V, Björklund P, Björklund B, et al: Keratin 8/18 breakdown and reorganization during apoptosis. Exp Cell Res 297: 11-26, 2004

19. Workman P, Aboagye EO, Balkwill F, Balmain A, Bruder G, Chaplin DJ, Double JA, Everitt J, Farningham DA, Glennie MJ, et al; Committee of the National Cancer Research Institute: Guidelines for the welfare and use of animals in cancer research. Br J Cancer 102: 1555-1577, 2010.

20. D'Incalci M, Colombo T, Ubezio P, Nicoletti I, Giavazzi R, Erba E, Ferrarese L, Meco D, Riccardi R, Sessa C, et al: The combination of yondelis and cisplatin is synergistic against human tumor xenografts. Eur J Cancer 39: 1920-1926, 2003.
21. Kapoor VK: Gallbladder cancer: A global perspective. J Surg Oncol 93: 607-609, 2006

22. Yamada N, Chung Y, Ohtani H, Ikeda T, Onoda N, Sawada T, Nishiguchi Y, Hasuma T and Sowa M: Establishment and characterization of a new human gallbladder carcinoma cell line (OCUG-1) producing TA-4. Int J Oncol 10: 1251-1255, 1997.

23. Kim WS, Jang KT, Choi DW, Choi SH, Heo JS, You DD and Lee HG: Clinicopathologic analysis of adenosquamous/ squamous cell carcinoma of the gallbladder. J Surg Oncol 103: 239-242, 2011.

24. Hamdani NH, Qadri SK, Aggarwalla R, Bhartia VK, Chaudhuri S, Debakshi S, Baig SJ and Pal NK: Clinicopathological study of gall bladder carcinoma with special reference to gallstones: Our 8-year experience from eastern India. Asian Pac J Cancer Prev 13: 5613-5617, 2012.

25. Chan KM, Yu MC, Lee WC, Jan YY and Chen MF: Adenosquamous/squamous cell carcinoma of the gallbladder. J Surg Oncol 95: 129-134, 2007.

26. Mingoli A, Brachini G, Petroni R, Antoniozzi A, Cavaliere F, Simonelli L, Chirletti P and Modini C: Squamous and adenosquamous cell carcinomas of the gallbladder. J Exp Clin Cancer Res 24: 143-150, 2005.

27. Miyanishi N, Nishi N, Abe H, Kashio Y, Shinonaga R, Nakakita S, Sumiyoshi W, Yamauchi A, Nakamura T, Hirashima M, et al: Carbohydrate-recognition domains of galectin-9 are involved in intermolecular interaction with galectin-9 itself and other members of the galectin family. Glycobiology 17: 423-432, 2007.

28. Matsumoto R, Matsumoto H, Seki M, Hata M, Asano Y, Kanegasaki S, Stevens RL and Hirashima M: Human ecalectin, a variant of human galectin-9, is a novel eosinophil chemoattractant produced by T lymphocytes. J Biol Chem 273: 16976-16984, 1998.

29. Kobayashi T, Kuroda J, Ashihara E, Oomizu S, Terui Y, Taniyama A, Adachi S, Takagi T, Yamamoto M, Sasaki N, et al: Galectin-9 exhibits anti-myeloma activity through JNK and p38 MAP kinase pathways. Leukemia 24: 843-850, 2010.

30. Leers MP, Kölgen W, Björklund V, Bergman T, Tribbick G, Persson B, Björklund P, Ramaekers FC, Björklund B, Nap M, et al: Immunocytochemical detection and mapping of a cytokeratin 18 neo-epitope exposed during early apoptosis. J Pathol 187: 567-572, 1999.

31. el-Deiry WS: Regulation of p53 downstream genes. Semin Cancer Biol 8: 345-357, 1998.

32. Batlle E, Bacani J, Begthel H, Jonkheer S, Gregorieff A, van de Born M, Malats N, Sancho E, Boon E, Pawson T, et al: EphB receptor activity suppresses colorectal cancer progression. Nature 435: 1126-1130, 2005.

33. Jägle S, Rönsch K, Timme S, Andrlová H, Bertrand M, Jäger M, Proske A, Schrempp M, Yousaf A, Michoel T, et al: Silencing of the EPHB3 tumor-suppressor gene in human colorectal cancer through decommissioning of a transcriptional enhancer. Proc Natl Acad Sci USA 111: 4886-4891, 2014.

34. Yuan Y, Yang ZL, Miao XY, Liu ZR, Li DQ, Zou Q, Li JH, Liang LF, Zeng GX and Chen SL: EphB1 and Ephrin-B, new potential biomarkers for squamous cell/adenosquamous carcinomas and adenocarcinomas of the gallbladder. Asian Pac J Cancer Prev 15: 1441-1446, 2014.

35. Ohuchida K, Mizumoto K, Lin C, Yamaguchi H, Ohtsuka T, Sato N, Toma H, Nakamura M, Nagai E, Hashizume M, et al: MicroRNA-10a is overexpressed in human pancreatic cancer and involved in its invasiveness partially via suppression of the HOXA1 gene. Ann Surg Oncol 19: 2394-2402, 2012.

36. Yu T, Liu L, Li J, Yan M, Lin H, Liu Y, Chu D, Tu H, Gu A and Yao M: MiRNA-10a is upregulated in NSCLC and may promote cancer by targeting PTEN. Oncotarget 6: 30239-30250, 2015

37. Cui R, Kim T, Fassan M, Meng W, Sun HL, Jeon YJ, Vicentini C, Tili E, Peng Y, Scarpa A, et al: MicroRNA-224 is implicated in lung cancer pathogenesis through targeting caspase-3 and caspase-7. Oncotarget 6: 21802-21815, 2015.

38. Yang C, Xu M, Shen HJ, Zhu HY, Li F, He M, Chen T, Wang J, Shi WJ and Ji F: Potential biomarkers for sensitivity of gallbladder cancer cells to gemcitabine. Int J Clin Exp Pathol 7: 521-528, 2014.

39. Plunkett W, Huang P, Searcy CE and Gandhi V: Gemcitabine: Preclinical pharmacology and mechanisms of action. Semin Oncol 23 (Suppl 10): 3-15, 1996.

40. Toyota Y, Iwama H, Kato K, Tani J, Katsura A, Miyata M, Fujiwara S, Fujita K, Sakamoto T, Fujimori T, et al: Mechanism of gemcitabine-induced suppression of human cholangiocellular carcinoma cell growth. Int J Oncol 47: 1293-1302, 2015. 